\title{
МОРСКИЕ ЗВЕЗДЫ КАК ПЕРСПЕКТИВНЫЙ ИСТОЧНИК БИОЛОГИЧЕСКИ АКТИВНЫХ СТЕРОИДНЫХ СОЕДИНЕНИЙ
}

\author{
Т.В. Маляренко, ${ }^{1,2}$ А.А. Кича', В.А. Стоник,,2, Н.В. Иванчина' \\ ${ }^{1}$ Лаборатория химии морских природных соединений, Федеральное государственное \\ бюджетное учреждение науки Тихоокеанский институт биоорганической химии им. Г.Б. \\ Елякова ДВО РАН, \\ 690022, Россия, г. Владивосток, пр. 100 лет Владивостоку, 159. \\ ${ }^{2}$ Кафедра биоорганической химии и биотехнологии, \\ Школа естественных наук, Дальневосточный Федеральный Университет, \\ 690000 , Россия, г. Владивосток,ул. Суханова, 8.
}

DOI: 10.19163/MedChemRussia2021-2021-158

E-mail: malyarenko-tv@mail.ru

Морские звезды (тип Echinodermata, класс Asteroidea), являясь типичными обитателями морского дна и активными хищниками, содержат разнообразные по своему химическому строению низкомолекулярные метаболиты: стерины, полярные стероидные соединения и их гликозиды, сфинголипиды, антрахиноновые пигменты и другие соединения. Интерес к низкомолекулярным соединениям морских звезд связан не только с их уникальным химическим строением, но и с разнообразной биологической активностью, которую проявляют данные метаболиты. Так, ранее нами было показано, что стероидные гликозиды из Echinaster luzonicus, Protoreaster lincki и Anthenea aspera уменьшали количество внутриклеточных форм активного кислорода в клетках RAW 264.7 мыши при индукции их провоспалительным эндотоксином липополисахаридом (ЛПС) из E. coli, что делает их потенциальными противовоспалительными агентами.

В последние годы нашей исследовательской группой было изучено несколько десятков новых полярных стероидных соединений различных структурных классов, имеющих редкие или уникальные структурные фрагменты. Для большинства из них было исследовано их действие на пролиферацию опухолевых клеток. Например, было показано, что лептаохотенсозид А из морской звезды Leptasterias ochotensis в нетоксичной концентрации показал ингибирующую активность на колониях клеток рака молочной железы T-47D. Установлено, что молекулярный механизм антипролиферативного действия лептаохотенсозида А связан с ингибированием фосфорилирования МАРкиназ (ERK1/2 и МСK-1). Кроме того, стероидные гликозиды из морской звезды Anthenea aspera обладали значительной ингибирующей активностью в отношении ряда опухолевых клеток, подавляя экспрессию антиапоптотических (Bcl-XL) и повышая экспрессию проапоптотических (Bax и Bak) белков.

Данная работа выполнена при поддержке гранта РНФ № 20-14-00040.

$$
-158-
$$

